\title{
Replacement of fishmeal by Leucaena leucocephala on the performance of local dairy calves of Bangladesh
}

\author{
MAS Khan
}

\author{
Dept of Dairy Science, Bangladesh Agricultural University, Mymensingh 2202, Bangladesh
}

In Bangladesh, locally produced fishmeal is available as a protein source for lactating cows and growing calves, and it responded very well Khan et al (1987, Bangladesh Vet J, 21, (3-4), 71-79). But some times it is scarce and expensive. So, there is a need to find an alternative, but similar to concentrate, such as legume which can be grown by the roadside, embankment and home. With the above understanding keeping in mind an experiment was carried out to assess the effect on the performance of calves by replacing fishmeal with fresh foliage from Leucaena leucocephala in the diet. Leucaena is a tree legume.

Nine local (indigenous) calves with an average age of 11 months and weighing an average of $55 \mathrm{~kg}$ were used to examine their performance by offering different sources of protein in their diets; the diets containing urea treated rice straw, green grass and wheat bran as basal feed with either $(\mathrm{kg} / \mathrm{d})$ fishmeal $(0.15)$, fishmeal $(0.08)$ plus Leucaena $(0.5)$ or only Leucaena (1.0). The diets were isoenergetic and isonitrogenous. The diets were designated as $A, B$, and $C$ respectively. The experiment started from 11 months of age of calves and continued for another 9 months.

It was found that the intakes of both energy and crude protein (CP) were similar (30 MJ

Parameters

Average daily gains $(\mathrm{g} / \mathrm{d})$

Average daily increment in height $(\mathrm{cm})$

Average daily increment in heart girth $(\mathrm{cm})$

Average daily increment in length $(\mathrm{cm})$
$\mathrm{ME} / \mathrm{d} / \mathrm{calf}$ and $355 \mathrm{~g} / \mathrm{d} /$ calf respectively) for all the three groups during the experimental period. Mean results for calves on diets $A, B$, and $C$ respectively, were weight gain $(g / d)$ 160, 143 and 101 ; daily increment in height (cm) $0.04,0.05$ and 0.05 ; in heart girth $(\mathrm{cm})$ $0.07,0.08$ and 0.07 ; and in length $(\mathrm{cm}) 0.07$, 0.05 and 0.05 . The differences among treatments were found significant $(P<0.05)$ except in height and heart girth. The differences in liveweight led to differences in the prices of calves at the end of the experiment.

The results suggests that the fishmeal has a positive effect on the performance of dairy calves mainly on the body weight gain and in length. But the cost of $\mathrm{C}$ diet i.e. $1 \mathrm{~kg}$ Leucaena (USD 0.13) was cheaper than those of diet A i.e. $0.15 \mathrm{~kg}$ fishmeal (USD 0.21) and diet B i.e. $0.08 \mathrm{~kg}$ fishmeal $+0.5 \mathrm{~kg}$ Leucaena (USD 0.18) and net return in terms of money on the basis of liveweight in diet $\mathrm{C}$ (USD 0.10) is also better than those of diet of A (USD 0.16) and diet B (USD 0.14) in comparison with feed cost. The choice of feed by the farmers whether they will use fishmeal or leucaena for their livestock depends on the price and availability of the feed.

\begin{tabular}{|c|c|c|}
\hline & - & \\
\hline Group-A & Group-B & Group-C \\
\hline $160 \mathrm{a}$ & $143^{b}$ & $101^{c}$ \\
\hline 0.04 & 0.05 & 0.05 \\
\hline 0.07 & 0.08 & 0.07 \\
\hline $0.07^{a}$ & $0.05^{b}$ & $0.05^{b}$ \\
\hline
\end{tabular}

